\title{
Forecasting the development of social infrastructure agriculture of the Chuvash republic
}

\author{
Tatiana Ivanova ${ }^{1, *}$, Nikolay Yakovchik ${ }^{2}$, Valery Chainikov ${ }^{1}$, Tatiana Kravchenko $^{1}$, and \\ Marina Mityugina ${ }^{1}$ \\ ${ }^{1}$ Chuvash State University named I.N. Ulyanov, Moskovsky prospect, 15, 428015 Cheboksary, \\ Russia \\ ${ }^{2}$ Educational institution "Belarusian State Agrarian Technical University", Independence Avenue, 99, \\ 220023 Minsk, Belarus
}

\begin{abstract}
The article discusses the development of the social infrastructure of agriculture in the Chuvash Republic for the period from 2009 to 2018. Agriculture occupies a special position in the region's economy and is a backbone industry. Its share in the gross regional product is $9 \%$, which is noticeably higher than in other regions of the country, and the share of residents living in rural areas is $36.6 \%$. With the help of the Excel program, a forecast of the development of rural social infrastructure for the most important indicators for 2019-2022 is presented. according to three scenarios: optimistic, probabilistic and pessimistic. As studies have shown, a pessimistic scenario is more likely to be implemented, which requires immediate corrective measures to effectively manage the industry, in particular, by creating a single "Chuvash Center for the Development of Rural Areas".
\end{abstract}

\section{Introduction}

Agriculture is a complex system, the development strategy of which goes beyond production and is largely determined by the state and prospects of solving social problems. This is also due to the fact that the demographic situation in the countryside is getting worse every year; the insufficient level of development of the countryside becomes the cause of interregional migration of the population, which leads to significant macroeconomic losses. In the Chuvash Republic, this industry is systemically important: the share of residents in rural areas in 2019 is $36.6 \% \square 1 \square$, and the share of agriculture in the GRP is $9 \% \square 2 \square$.

The purpose of the article is, based on statistical data on the main indicators of the social infrastructure of agriculture in the Chuvash Republic, to calculate their predicted values to substantiate development scenarios and effective management.

To achieve this goal, the following tasks must be solved: to determine the list of indicators characterizing the development of the social infrastructure of agriculture in the

\footnotetext{
${ }^{*}$ Corresponding author: ivanovatv85@mail.ru
} 
Chuvash Republic; analyze them; develop optimistic, probabilistic and pessimistic forecast options; to give recommendations on the application of the obtained data. In the course of the study, the following tools were used: analysis and synthesis, correlation and regression analysis, statistical and systemic approaches. To build graphs of the development of the situation in the agriculture of the Chuvash Republic until 2022, the MS Excel application was used.

\section{Materials and methods}

Analyzing foreign publications over the past five years $\square 3-13 \square$ and taking into account the absence of similar works on these issues in the Chuvash Republic (except for the author's $\square$ 14-17 $\square$ ), we came to the conclusion that the research technologies used in them are based on only on analysis, which does not allow forecasting. In contrast to the presented publications, this paper proposes to use the mathematical apparatus to substantiate the development of the social infrastructure of agriculture and, based on forecasts, to carry out effective leadership.

Let us consider the main indicators characterizing the development of the social infrastructure of agriculture in the Chuvash Republic for the period from 2009 to 2018 (Table 1).

Table 1. Indicators of the development of social infrastructure in agriculture Chuvash Republic for 2010-2019 [18].

\begin{tabular}{|c|c|c|c|c|c|c|c|c|c|c|}
\hline \multirow[t]{2}{*}{ Indicators } & \multicolumn{10}{|c|}{ Years } \\
\hline & 2009 & 2010 & 2011 & 2012 & 2013 & 2014 & 2015 & 2016 & 2017 & 2018 \\
\hline \multicolumn{11}{|l|}{$\begin{array}{l}\text { Commissioning in } \\
\text { rural areas: }\end{array}$} \\
\hline $\begin{array}{c}\text { - residential } \\
\text { buildings, thousand } \mathrm{m} \\
\text { of total area }\end{array}$ & 452.7 & 456.2 & 488.0 & 418.3 & 387.3 & 376.1 & 311.8 & 200.0 & 161.1 & 118.2 \\
\hline $\begin{array}{c}\text { - educational } \\
\text { institutions, student } \\
\text { places }\end{array}$ & 690 & - & 140 & 340 & 1060 & - & 205 & 165 & - & 229 \\
\hline $\begin{array}{c}\text { - preschool } \\
\text { institutions, places }\end{array}$ & - & 90 & - & 490 & 470 & 793 & 345 & 40 & - & - \\
\hline $\begin{array}{l}\text { - cultural institutions } \\
\text { club type, places }\end{array}$ & - & - & - & - & 351 & 120 & - & 280 & 439 & 500 \\
\hline - hospitals, beds & 20 & - & - & - & - & - & - & - & - & - \\
\hline $\begin{array}{l}\text { - outpatient clinics, } \\
\text { visits per shift }\end{array}$ & 250 & 15 & 15 & 60 & 720 & 1200 & 1200 & $\mathrm{n} / \mathrm{d}$ & $\mathrm{n} / \mathrm{d}$ & $\mathrm{n} / \mathrm{d}$ \\
\hline $\begin{array}{c}\text { - utility facilities, } \\
\text { kilometers: } \\
\text { Water supply } \\
\text { networks }\end{array}$ & 39.4 & 56.7 & 28.1 & 19.8 & 5.1 & 6.0 & 8.2 & 0.1 & 5.1 & 8.2 \\
\hline Sewer networks & - & - & - & - & 5.2 & - & 1.0 & - & - & - \\
\hline Heating networks & 0.7 & - & 0.1 & - & 0.3 & - & 2.1 & - & - & - \\
\hline Gas networks & 15.2 & 30.5 & 35.5 & 45.4 & 67.9 & 58.0 & 54.7 & 43.0 & 41.1 & 59.8 \\
\hline
\end{tabular}

Analyzing the data in the table 1 , it can be seen that the commissioning of residential buildings in rural areas of the Chuvash Republic decreased from 2009 to 2018 by 334.5 
thousand $\mathrm{m}$ of the total area, or 3.83 times; educational institutions - for 461 student places, or 3 times. Also, during the analyzed period, there is a decrease in the value of the parameter of commissioning of water supply networks - by 31.2 kilometers and an increase in gas networks - by 44.6 kilometers, or 3.93 times.

For some indicators, there were no changes in different years or they were insignificant. For example, on the commissioning in rural areas: preschool and cultural institutions of the club type, sewer and heating networks, hospitals and outpatient clinics. The lack of indicators for the last two parameters is due to the fact that the health care system is gradually moving to new performance criteria.

Namely: the effectiveness of state, regional and municipal health care management; assessment of medical and economic efficiency and selection of individual large alternative medical programs and methods of prevention and treatment that are optimal for the entire population, but not for an individual; medical and economic efficiency of multidisciplinary clinical hospitals and their departments. The commissioning of educational institutions in 2010, 2014 and 2017 was not carried out, and the lack of values will not allow building a qualitative forecast. In this regard, we will not use them in our further calculations, since it is impossible to carry out objective forecasting based on them.

\section{Results and discussion}

Thus, based on the dynamics of indicators characterizing the development of the social infrastructure of agriculture in the Chuvash Republic for 2009-2018 and using the Excel program, in table 2, the equations of three options for the development of the situation for 2019-2022 are derived (optimistic, probabilistic and pessimistic) on three indicators.

Table 2. Forecast of changes in indicators characterizing the development of social infrastructure of agriculture in the Chuvash Republic until 2022.

\begin{tabular}{|c|c|c|c|c|c|c|c|}
\hline \multirow[t]{2}{*}{ Option forecast } & \multirow[t]{2}{*}{ Equation } & \multicolumn{5}{|c|}{ Year } & \multirow{2}{*}{$\begin{array}{c}2022 \\
\text { by } \\
2018, \\
\%\end{array}$} \\
\hline & & 2018 & 2019 & 2020 & 2021 & 2022 & \\
\hline \multicolumn{8}{|c|}{ Commissioning in rural areas: residential buildings, thousand $m$} \\
\hline Optimistic & $\begin{array}{c}y=-0.2763 x^{2}-41.251 x \\
+542.61\end{array}$ & \multirow{3}{*}{118.2} & 110.9 & 62.7 & 15.1 & -32 & -27.1 \\
\hline Probabilistic & $\begin{array}{c}y=-0.6204 x^{2}-38.728 x \\
+539.46\end{array}$ & & 87.0 & 39.6 & -7.8 & -55.2 & -46.7 \\
\hline Pessimistic & $\begin{array}{c}\mathrm{y}=-0.7531 \mathrm{x}^{2}-37.976 \mathrm{x} \\
+538.92\end{array}$ & & 68.8 & 28.5 & -13.2 & -67.7 & -57.3 \\
\hline \multicolumn{8}{|c|}{ water supply networks, kilometers } \\
\hline Optimistic & $\begin{array}{c}y=0.2194 x^{2}-7.7545 x \\
+51.762\end{array}$ & \multirow{3}{*}{8.2} & 1.6 & -8.9 & -16.2 & -20.1 & -245.1 \\
\hline Probabilistic & $\begin{array}{c}\mathrm{y}=0.1735 \mathrm{x}^{2}-7.5472 \mathrm{x} \\
+51.806\end{array}$ & & -9.5 & -14.5 & -19.4 & -24.4 & -297.6 \\
\hline Pessimistic & $\begin{array}{c}y=0.0875 x^{2}-6.7694 x \\
+50.577\end{array}$ & & -14.3 & -19.8 & -26.3 & -30.2 & -368.3 \\
\hline \multicolumn{8}{|c|}{ gas networks, kilometers } \\
\hline Optimistic & $\mathrm{y}=19.811 \ln (\mathrm{x})+16.81$ & \multirow{3}{*}{59.8} & 66.1 & 69.4 & 72.3 & 75.5 & 126.3 \\
\hline Probabilistic & $y=18.636 \ln (x)+18.015$ & & 62.8 & 66.0 & 69.3 & 72.5 & 121.2 \\
\hline Pessimistic & $y=17.254 \ln (x)+19.447$ & & 59.2 & 62.7 & 65.9 & 68.0 & 113.7 \\
\hline
\end{tabular}

In Fig. 1-9, forecast graphs are built (numerals on the $x$-axis mean years) for the indicators in Table 2. It can be seen from them that for all forecast options, the approximation coefficient $R^{2}$ ranges from 0.7086 to $0.9803 . R^{2}$ is an indicator of the quality 
of forecasts: the closer its value is to one, the higher the probability of execution. So, for the commissioning of residential buildings in rural areas of the Chuvash Republic until 2022, $R^{2}$ has a maximum value with a pessimistic forecast -0.9803 . Consequently, it is more likely, about $98 \%$, to be realized. The pessimistic forecast with a probability of $87 \%$ will also be fulfilled for the commissioning of water supply networks. And for the forecast of the commissioning of gas networks, an optimistic forecast will be implemented (with a value of $74 \%$ ).

Three of the nine constructed forecasts have values of $R^{2}>0.97$, which proves the accuracy of the calculations performed with $97 \%$ probability; three variants of forecasts have $R^{2}>0.83$ ( $83 \%$ probability), for three more variants $R^{2}>0.71$ ( $71 \%$ probability).

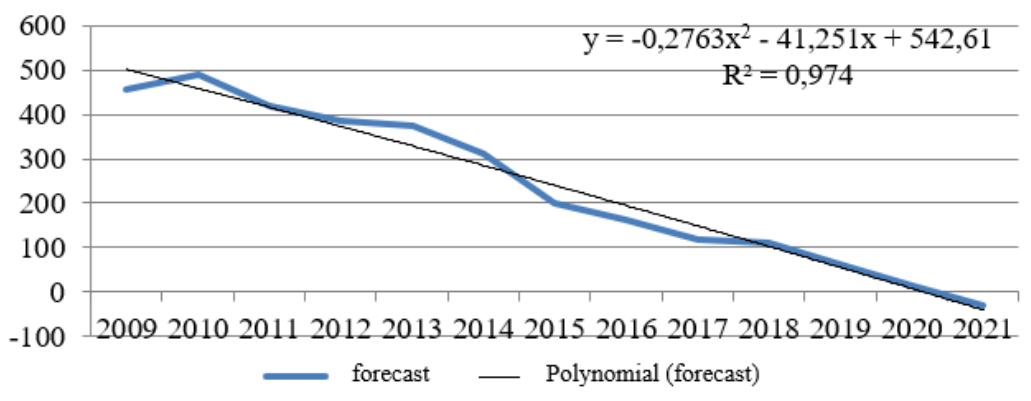

Fig. 1. Optimistic forecast for commissioning in rural areas of the Chuvash Republic of residential buildings until 2022, thousand sq.

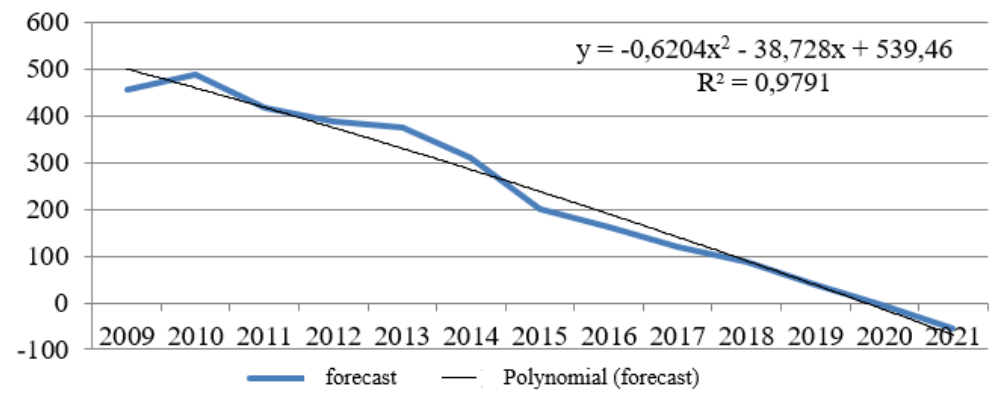

Fig. 2. Probabilistic forecast for commissioning in rural areas of the Chuvash Republic of residential buildings until 2022, thousand sq.

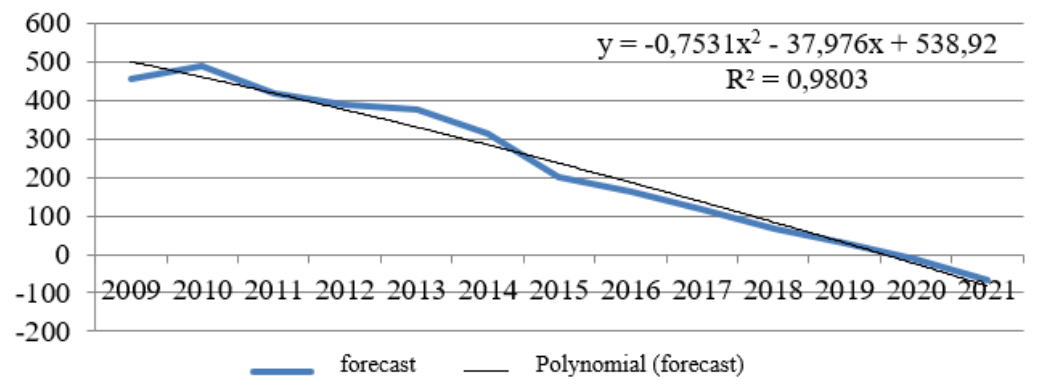

Fig.3. Pessimistic forecast for commissioning in rural areas of the Chuvash Republic of residential buildings until 2022, thousand sq. 


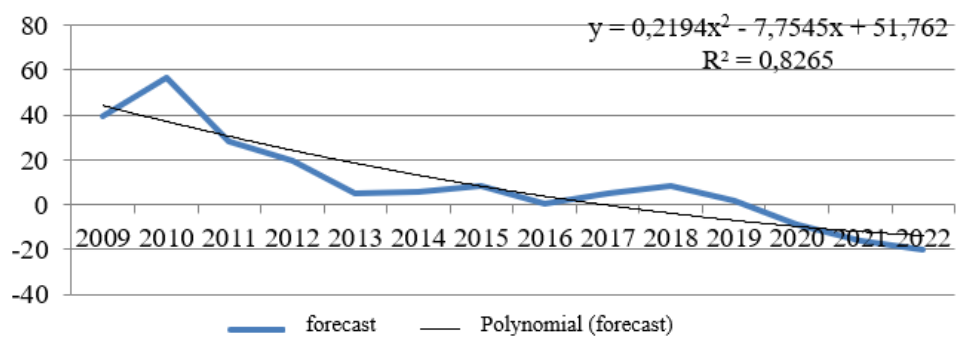

Fig. 4. Optimistic forecast for commissioning in rural areas of the Chuvash Republic of water supply networks until 2022, $\mathrm{km}$.

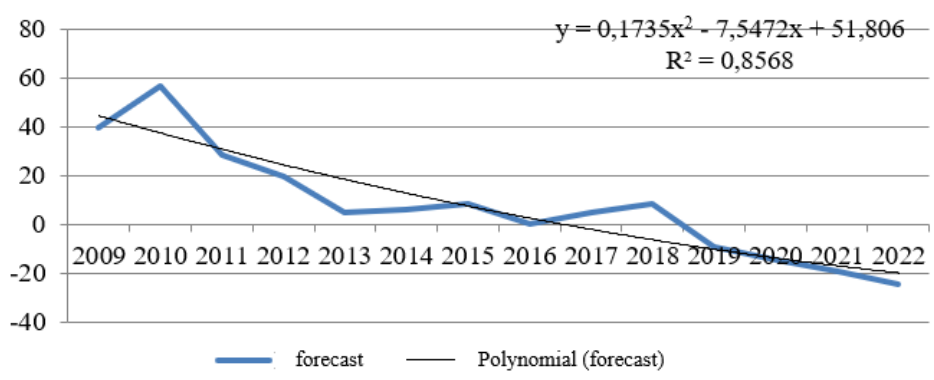

Fig.5. Pessimistic forecast for commissioning in rural areas of the Chuvash Republic of water supply networks until 2022, $\mathrm{km}$.

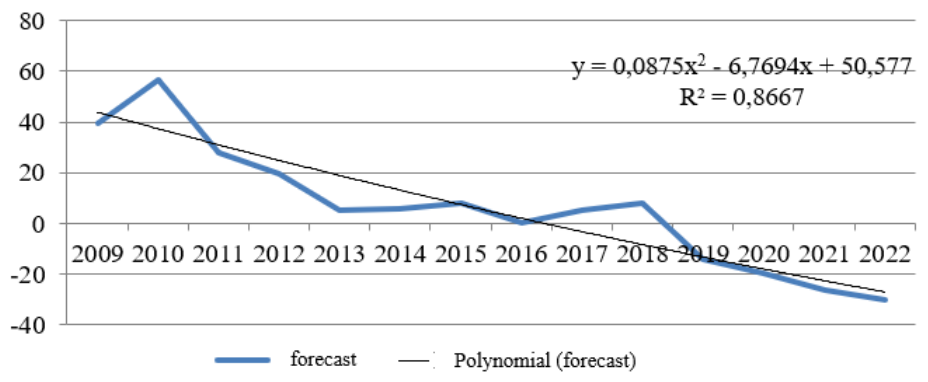

Fig.6. Pessimistic forecast for commissioning in rural areas of the Chuvash Republic of water supply networks until 2022, $\mathrm{km}$.

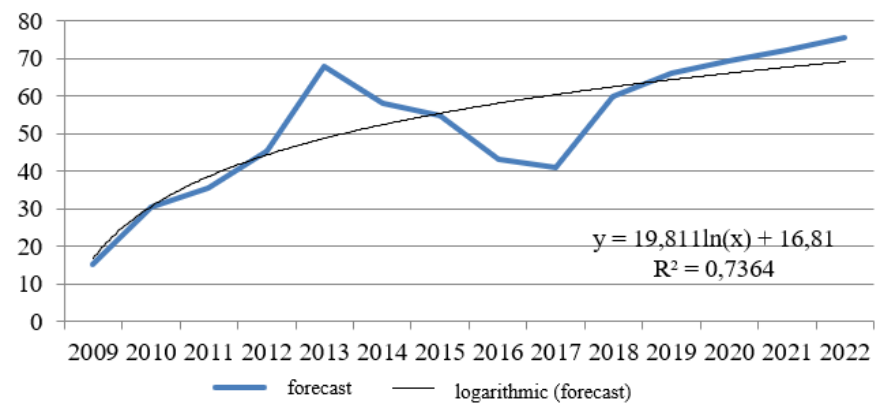

Fig. 7. Optimistic forecast for commissioning in rural areas of the Chuvash Republic of gas networks until 2022, $\mathrm{km}$. 


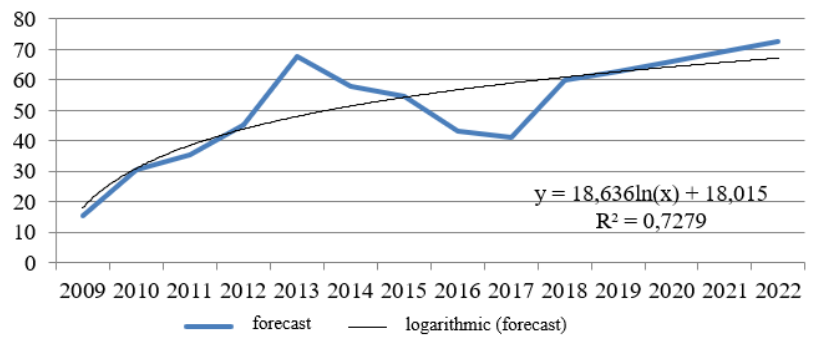

Fig. 8. Probabilistic forecast for commissioning in rural areas of the Chuvash Republic of gas networks until 2022, $\mathrm{km}$.

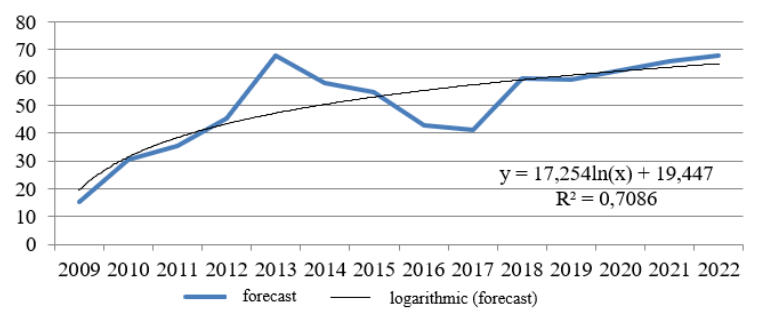

Fig.9. Pessimistic forecast for commissioning in rural areas of the Chuvash Republic of gas networks until 2022, $\mathrm{km}$.

\section{Conclusions}

Based on the three forecast options (Table 2), it can be seen that the maximum growth is planned for such an indicator as the commissioning of gas networks in rural areas of the Chuvash Republic. Even with a pessimistic forecast, it will amount to $113.7 \%$ in 2022 in relation to 2018. However, in two other positions: the commissioning of residential buildings and gas networks - a decrease in values is expected in 2022 even with an optimistic forecast. This situation should serve as a trigger for the development of corrective actions, since without this, the sustainable functioning of agriculture is impossible. If you do not take any action in a timely manner, then the process will only worsen. The task of state bodies is to react in time to the prevailing forecast trends in order to mitigate their influence.

However, even if investments flow into agriculture, then in this case it will be impossible to solve the problems only by administrative methods; a new level of development of the village and its new dimension are associated with the formation of the peasant as a citizen. The village as a single territorial-production and socio-cultural complex can only develop with a combination of two mutually stimulating factors: positive changes in the outlook of rural residents should be supported by economic transformations.

In order to effectively manage agriculture, a single "Chuvash Center for the Development of Rural Areas" should be created (Fig. 10). 


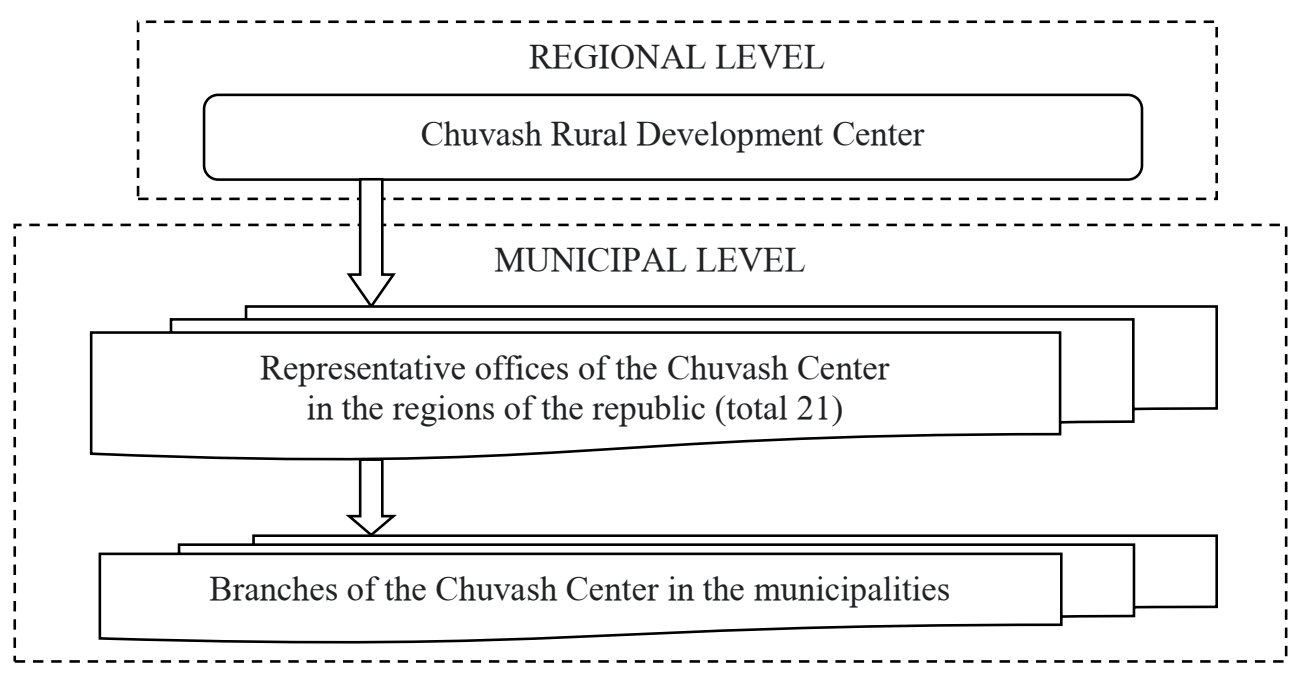

Fig. 10. Rural Development Support Infrastructure in the Chuvash Republic.

This center, as an object of special responsibility of the state in the countryside, in our opinion, should contribute to the sustainable development of rural areas of the Chuvash Republic by performing a number of functions, namely:

1. Promote the creation of a new type of rural settlements with ensuring equal accessibility to social infrastructure and services for all groups of the rural population.

2. To regulate the infrastructure of the rural labor market and orient its objects to ensure year-round employment.

3. Monitor the fulfillment of direct obligations of the state and employers to rural residents and employees of agricultural organizations.

4. To contribute to ensuring a high educational, professional and living standard of rural residents.

5. Develop a methodology for assessing the cost of living necessary for the reproduction of biophysical, labor, intellectual and social capital of various categories of rural residents and oblige agricultural organizations to use it in calculating wages.

6. To promote the formation of a middle class and an entrepreneurial environment in the countryside.

Today, in the region, these issues are dealt with by the Department of Investment and Social Development of the Village of the Ministry of Agriculture of the Chuvash Republic, consisting of 4 people, which is a negligible figure for a region where $36.6 \%$ live in rural areas. Moreover, the functions of the department are only in regulating the processes of development of rural areas, and the functional itself should be located "in the field" - in districts, rural settlements, etc. This recommendation is especially relevant in connection with the abolition of the Agricultural Departments and their transformation into departments within the regional administrations.

Thus, effective agricultural management largely depends on competent and timely government support, including through the creation of an appropriate social infrastructure. And the developed forecast is a mathematical justification of the decisions made, representing one of the grounds for the legislative and executive authorities in the development of socio-economic projects and programs. In addition, the research results can be used in practice by agricultural enterprises, university professors, graduate students, as well as those who are interested in management and organization of agricultural production. 


\section{References}

1. Regions of Russia. Socio-economic indicators - 2020, http://gks.ru

2. About the structure of the gross regional product of the Chuvash Republic, http://minec.cap.ru

3. E. G. Bongiorno, A. Goia, Journal of Multivariate Analysis, 170 (2019)

4. S. A. Cole, W. Xiong, Annual Review of Economics, 9 (2017)

5. L. Hilty, B. Aebischer. ICT innovations for sustainability (2015)

6. D. Kosiorowski, J. P. Rydlewski, Centrality-oriented Causality-A Study of EU Agricultural Subsidies and Digital Developement in Poland (2019)

7. S. J. Lee, E. H. Lee, D. S. Oh, World Technopolis Review, 6(1) (2017)

8. N. N. Minina, Achievements of science and technology of the agro-industrial complex, 32(1) (2018)

9. R. Njos, S. E. Jakobsen, Regional Studies, Regional Science, 3(1) (2016)

10. A. N. Stavtsev, G. A. Miroshnikov, RJOAS, 1(49) (2016)

11. A. Tacchella, D. Mazzilli, L. Pietronero, Nature Physics, 14(8) (2018)

12. M. Tahamipour, M. Mahmoudi, Macrothink Institute: Research in Applied Economics, 10(1) (2018)

13. D. Yoon, Journal of Science and Technology Policy Management, 8(2) (2017)

14. T. V. Ivanova, Scientific works of the Institute of Economics of the National Academy of Sciences of Azerbaijan, 4 (2017)

15. T. V. Ivanova, A. A. Ivanova, IOP Conf. Series: Earth and Environmental Science, 613, 012049 (2020)

16. V. N. Orlov, T. V. Ivanova, V. A. Arkhipova, I. P. Ivanitskaya, PbWOSCE-2018: Business technologies for sustainable urban development. E3S Web Conf., 110 (2019)

17. V. N. Orlov, T. V. Ivanova, S. A. Brechagova, N. N. Rumbayeva, IOP Conf. Series: Earth and Environmental Science, 433, 012012 (2020)

18. Agro-industrial complex of Russia in 2018: Statistical compilation (2019) 